\title{
EVALUATING THE CRUCIAL FACTORS AFFECTING HYDROGEN GAS GENERATION FROM MUNICIPAL SOLID WASTE INCINERATION BOTTOM ASH (MSWIBA)
}

\author{
Masayasu Miyake ${ }^{1, *}$, Teppei Komiya ${ }^{2}$, Amirhomayoun Saffarzadeh ${ }^{2}$ and Takayuki \\ Shimaoka ${ }^{2}$
}

${ }^{1}$ Department of Urban and Environmental Engineering, Graduate School of Engineering, Kyushu University, 744 Motooka Nishi-ku, Fukuoka 819-0395, Japan

${ }^{2}$ Department of Urban and Environmental Engineering, Faculty of Engineering, Kyushu University, 744 Motooka Nishi-ku, Fukuoka 819-0395, Japan

Article Info:
Received:
7 March 2018
Revised:
15 May 2018
Accepted:
31 May 2018
Available online:
30 June 2018
Keywords:
Hydrogen gas
MSWIBA
Bottom ash
Carbon-free energy
pH

\section{INTRODUCTION}

Approximately 44.0 million tons of municipal solid waste (MSW) was generated in Japan in $2015,80 \%$ of which was incinerated. This resulted in the generation of approximately 3.2 million tons of MSW incineration residue, which was disposed of mainly in sanitary landfills (Ministry of the Environment of Japan, 2017). MSW incineration bottom ash (MSWIBA) contains an appreciable amount of metal aluminum that is distributed throughout various particle fractions of bottom ash. (Saffarzadeh et al., 2016; Arumugam, 2016). Hydrogen gas is generated by an aluminum-assisted water splitting reaction, which can be given by the following equation (Armstrong and Braham, 1996; Takatsuki, 1994; Toyofuku, 1989):

$2 \mathrm{Al}+6 \mathrm{H}_{2} \mathrm{O} \rightarrow 2 \mathrm{Al}(\mathrm{OH})_{3}+3 \mathrm{H}_{2} \uparrow$

Bottom ash imparts alkalinity to the reacting solution because it contains a large amount of $\mathrm{Ca}$ compounds. Hydrogen gas is generated through the reaction between water and essentially the metal aluminum in the bottom ash. When the hydration reaction proceeds in MSWIBA, a layer of hydrate is formed on the surface of the metal aluminum (Saffarzadeh et al., 2016), which prevents the aluminum from coming into further contact with the water. This is one of the reasons why hydrogen gas generation decreases over time.

Hydrogen gas is the only carbon-free energy source and its energy potential is higher than that of other known fuels, such as methane, ethane, and gasoline (Marbán \& Valdés-Solís, 2006; Marbán et al., 2006; Shinnar, 2003; Granovskii et al, 2006). A newly developed energy source can replace fossil fuels. When hydrogen in fuel cells is subject to direct combustion, it is possible to generate energy without the production of $\mathrm{CO}_{2}$, because water is the only by-product formed (DeLuchi, 1989; Momirlan \& Veziroglu, 2002; Momirlan \& Veziroglu, 2005).

If the generated hydrogen gas can be efficiently recovered, MSWIBA may be considered a source of hydrogen for energy production. To make the system of hydrogen gas generation from bottom ash and water practically feasible, it is necessary to reduce the production unit cost. Additionally, it is necessary to understand the most suitable conditions for efficient collection of the hydrogen gas. The most critical parameters are reaction temperature, stirring rate, and liquid-solid ratio. If the amount of water $(\mathrm{l} / \mathrm{s})$ required for hydrogen gas generation is reduced, it would be possible to reduce the amount of waste liquid after collection
* Corresponding author:

Masayasu Miyake

email: miyake-m@doc.kyushu-u.ac.jp 
of the hydrogen gas. Equipment for mixing and stirring of bottom ash with water is also necessary. The size of the equipment depends on the amount of bottom ash and the time until completion of hydrogen gas generation with mixing and stirring. For these reasons, a shorter mixing and stirring time is important, and it is also necessary to consider accelerating the hydrogen gas generation process.

The purpose of this study was to elucidate the factors influencing the hydrogen gas generation from MSWIBA and to determine whether hydrogen gas generation can be promoted by crushing the bottom ash. A series of mixing and stirring experiments using bottom ash and water were conducted by regulating the reaction temperature, liquid-solid ratio, stirring rate, and the presence or absence of grinding treatment as the experimental parameters.

\section{MATERIAL AND METHODS}

\subsection{Sampling}

Bottom ash sample was collected from the incineration facilities S (Stoker-type, 750 t/day) and R (Stoker-type, 900 $t /$ day) located in the F. city in Japan. Bottom ash from the $S$ plant is hereinafter referred to as S-BA and that from the $\mathrm{R}$ plant as R-BA. The S-BA was sieved to less than $9.5 \mathrm{~mm}$ in diameter. Ferrous metals were manually removed from R-BA by a magnet and subsequently sieved to less than 30 $\mathrm{mm}$ in diameter. The R-BA was only used to evaluate the promotion of hydrogen gas generation. The samples were air-dried and then oven-dried at $65^{\circ} \mathrm{C}$ for 24 hours to remove moisture and minimize the effect of weathering. The samples were dried at $105^{\circ} \mathrm{C}$, crushed to less than $0.5 \mathrm{~mm}$, boiled in $\mathrm{HCl}(1 \mathrm{~mol} / \mathrm{l})$ for $30 \mathrm{~min}$ and then metal aluminum contents in the samples were measured by an atomic absorption spectrophotometer (UV-1230, Japan, SHIMADZU CORPORATION). The S-BA and R-BA contained 3.9 and $3.8 \%$ of metal aluminum by mass percentage, respectively.

To enhance hydrogen gas generation, S-BA was crushed to less than $45 \mu \mathrm{m}$ by a vibration mill and R-BA was crushed to $4.2 \mu \mathrm{m}$ in average particle size by a cutting mill and a jet mill. A cutting mill that was a crusher using blades, was used to reduce sample particle size to be suitable for the jet mill. The jet mill was a crusher using a high speed jet of compressed air. Sample particles were crushed by mutual contact. Particles that could not be crushed during the milling process were excluded from the experiments because it was presumed that the crushed and non-crushed bottom ash samples had the same metal aluminum contents.

\subsection{Stirring and mixing experiment using bottom ash and water}

Figure 1 shows a schematic diagram of the experimental setup, which included a reactor, liquid collection bottles, hydrogen gas concentration sensor, and flowmeter, all of which were connected by the PVC tubes. The bottom ash and water were mixed and stirred in the reactor, which could maintain a constant temperature and change the stirring rate. Hydrogen gas, generated in the reactor, flowed through the tube and passed through a liquid collection bottle to cool it and condense water vapor. The gas passed

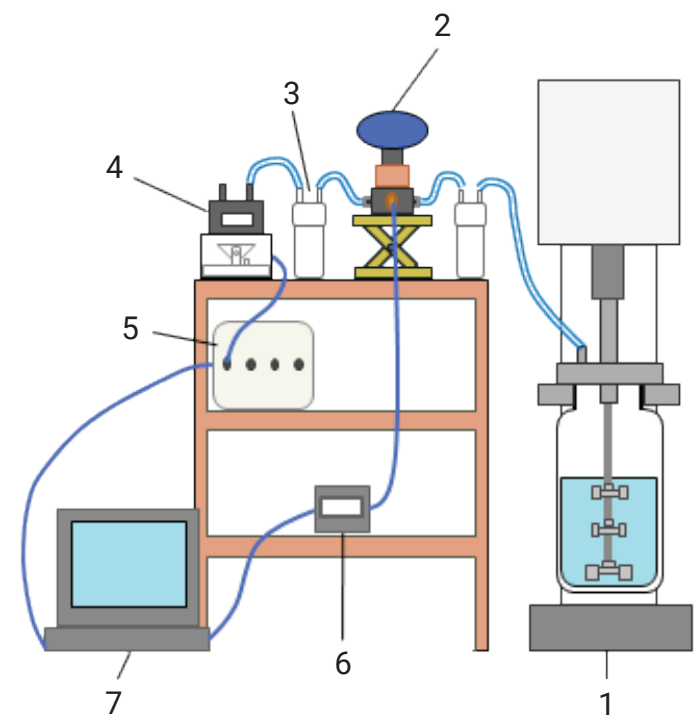

FIGURE 1: Schematic diagram of the experimental setup. 1) Reactor, 2) Sensor of hydrogen gas concentration, 3) Liquid collection bottle, 4) Flowmeter, 5) Data logger, 6) Display of hydrogen gas concentration, 7) PC.

through the sensor, followed by the liquid collection bottle, which prevented the breakdown of the sensor from the backflow of the flowmeter oil, and finally the flowmeter. Hydrogen gas concentration was measured at intervals of 1 minute during the experiment. The amount of gas generated was measured every $3.24 \mathrm{~mL}$ which was the collection capacity of the flowmeter. In the experiments, $500 \mathrm{~g}$ of the samples were used. Before the experiment began, the gas in the entire setup was substituted with nitrogen by purging $1 \mathrm{~L} / \mathrm{min}$ of nitrogen gas for $5 \mathrm{~min}$. Table 1 shows the experimental conditions.

\section{RESULTS AND DISCUSSION}

\subsection{Consideration of the factors that influence hy- drogen gas generation}

\subsubsection{Influence by reaction temperature}

Figure 2 shows the relationship between hydrogen gas generation and time. At $50^{\circ} \mathrm{C}$, the highest amount of hydrogen generated was $11.4 \mathrm{~m}^{3} / \mathrm{t}$-ash, and the shortest experiment time of 13.0 days was achieved. At $40^{\circ} \mathrm{C}, 10.4$ $\mathrm{m}^{3} / \mathrm{t}$-ash of hydrogen gas was generated over 21.0 days. At $60^{\circ} \mathrm{C}$, the amount of hydrogen gas generated was 10.2 $\mathrm{m}^{3} / \mathrm{t}$-ash over 20.5 days. According to the research of Zhao, $Z$ et al., 2011, the chemical reaction rate increases when temperature increase. However, when temperature increase, also the concentration of $\mathrm{OH}$ - is decrease lead to the reduce of hydrogen generated. And the chemical reaction is heat dissipation reaction. For these reasons, the same phenomenon occurs in this study, at $50^{\circ} \mathrm{C}$ the amount of hydrogen generated was the highest, compare to $40^{\circ} \mathrm{C}$ and $60^{\circ} \mathrm{C}$.

\subsubsection{Influence of the liquid-solid ratio $(\mathrm{l} / \mathrm{s})$}

According to Figure 3 , at $\mathrm{l} / \mathrm{s}=3,7.9 \mathrm{~m}^{3} / \mathrm{t}$-ash of hydrogen gas was generated over 14.6 days. This was about 
TABLE 1: Experimental conditions.

\begin{tabular}{|c|c|c|c|c|c|}
\hline Case & Sample & $\begin{array}{c}\text { Reaction } \\
\text { Temperature }\left({ }^{\circ} \mathrm{C}\right)\end{array}$ & $1 / s$ & $\begin{array}{l}\text { Stirring } \\
\text { rate (rpm) }\end{array}$ & $\begin{array}{l}\text { Crushing } \\
\text { process }\end{array}$ \\
\hline 1 & \multirow{7}{*}{ S-BA } & 40 & \multirow{3}{*}{5} & \multirow{4}{*}{600} & \multirow{6}{*}{ Non-crushed } \\
\hline 2 & & 50 & & & \\
\hline 3 & & 60 & & & \\
\hline 4 & & \multirow{6}{*}{50} & 3 & & \\
\hline 5 & & & \multirow{5}{*}{5} & 400 & \\
\hline 6 & & & & 800 & \\
\hline 7 & & & & \multirow{3}{*}{600} & Crushed \\
\hline 8 & \multirow{2}{*}{$\mathrm{R}-\mathrm{BA}$} & & & & Non-crushed \\
\hline 9 & & & & & Crushed \\
\hline
\end{tabular}

$3.5 \mathrm{~m}^{3} / \mathrm{t}$-ash lower than that produced at $\mathrm{l} / \mathrm{s}=5$. At $\mathrm{l} / \mathrm{s}=$ 3 , the precipitation of bottom ash particles was identified in the reactor. This could be because the mixing of bottom ash with water was insufficient at lower I/s. Therefore, I/s should be greater than 3 .

\subsubsection{Influence of stirring rate}

As displayed in Figure 4, the highest amount of hydrogen gas generated was $11.4 \mathrm{~m}^{3} / \mathrm{t}$-ash at $600 \mathrm{rpm}$. The second highest amount of hydrogen gas generated was $11.0 \mathrm{~m}^{3} / \mathrm{t}$-ash at $800 \mathrm{rpm}$. The lowest amount of hydrogen gas generated was $6.8 \mathrm{~m}^{3} / \mathrm{t}$-ash at $400 \mathrm{rpm}$. At $400 \mathrm{rpm}$, bottom ash and water were not sufficiently stirred and mixed in the reactor, as was the case when $\mathrm{l} / \mathrm{s}=3\left(50^{\circ} \mathrm{C}\right.$, $600 \mathrm{rpm})$. The amount of bottom ash precipitated in the solution increased, which is why hydrogen gas generation decreased. The stirring rate should, therefore, be greater than $400 \mathrm{rpm}$. It is possible to achieve a practical hydrogen gas generation volume and speed even at $400 \mathrm{rpm}$ or less if the stirring efficiency of bottom ash and water increases by optimizing the shapes of the stirring blades and reactor.

\subsection{Promotion of hydrogen gas generation by crush- ing}

In the case of S-BA, $6.6 \mathrm{~m}^{3} / \mathrm{t}$-ash of hydrogen gas was generated from crushed S-BA and water. This was approximately $4.8 \mathrm{~m}^{3} / \mathrm{t}$-ash lower than that for the non-crushed bottom ash (Figure 5). In the case of R-BA, $5.1 \mathrm{~m}^{3} / \mathrm{t}$-ash of hydrogen gas was generated from crushed R-BA and water. This was approximately $7.6 \mathrm{~m}^{3} / \mathrm{t}$-ash less than for the noncrushed bottom ash (Figure 6).

Conversely, the initial gradient of hydrogen gas generation (i.e. from 0 to $20 \%$ ) increased. In the case of S-BA, this was from $3.8 \mathrm{~m}^{3} / \mathrm{t}$-ash/day when non-crushed S-BA was used to $274.5 \mathrm{~m}^{3} / \mathrm{t}$-ash/day when crushed S-BA was used. In the case of R-BA, this decreased from $8.2 \mathrm{~m}^{3} / \mathrm{t}$-ash/day for non-crushed R-BA to $135.1 \mathrm{~m}^{3} / \mathrm{t}$-ash/day for crushed $\mathrm{R}-\mathrm{BA}$. The initial gradient of hydrogen gas generation increased significantly by crushing; however, the cumulative amount of hydrogen gas generation decreased. Because of the rigorous crushing of $\mathrm{BA}$, metal aluminum that is presumed to trigger hydrogen generation has turned to very fine particulates with significantly large surface areas. As a

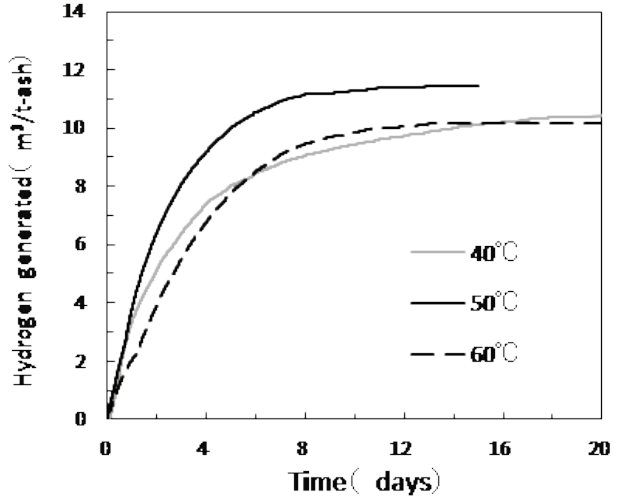

FIGURE 2: Influence of reaction temperature.

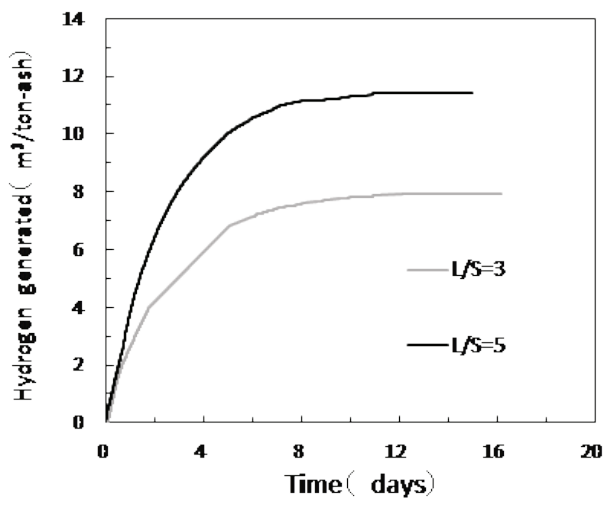

FIGURE 3: Influence of liquid solid ratio.

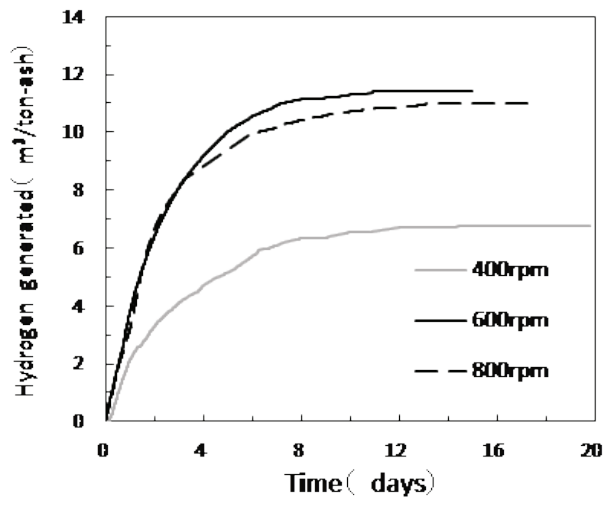

FIGURE 4: Influence of stirring rate. 


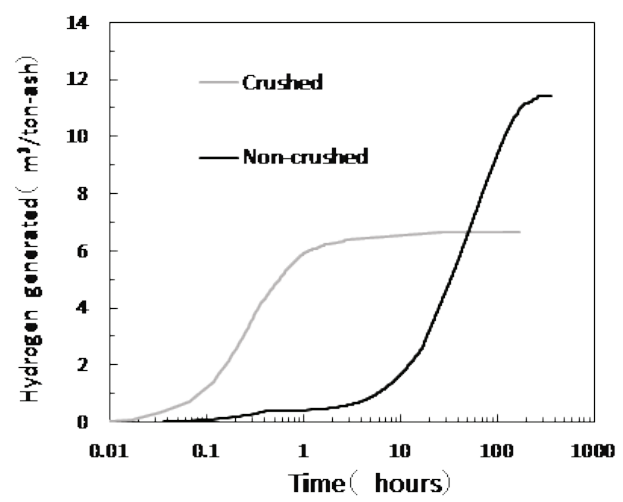

FIGURE 5: Promotion effect by crushing process (S-BA).

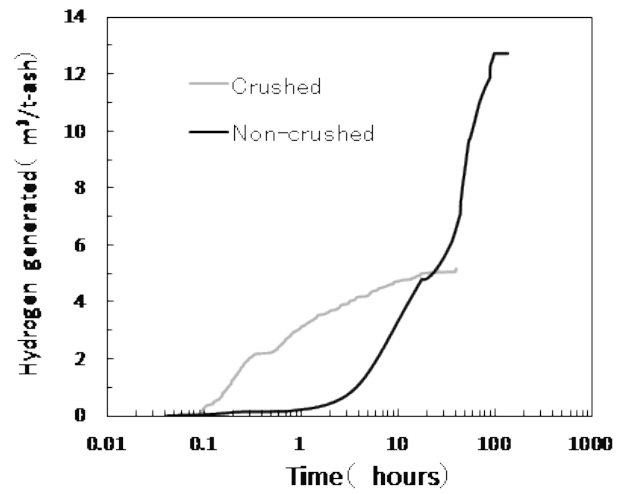

FIGURE 6: Promotion effect by crushing process (R-BA).

result, the corrosion rate of such fine metallic particulates has considerably accelerated and they rapidly consumed at the beginning of the reactions. Therefore, almost no or little reactive metal aluminum remained for the advanced steps of the experiment that resulted in lower cumulative hydrogen in the crushed BA.

\subsection{Relationship between hydrogen gas generation and $\mathrm{pH}$}

Table 2 shows the volume of hydrogen gas generated and the $\mathrm{pH}$ of the liquid phase when the experiment completed. At the end of the experiment, the $\mathrm{pH}$ was within 10.9-12.0 when S-BA and R-BA were used. There is no no- ticeable relationship with reaction temperature or stirring rate. Mixing and stirring were insufficient for cases 4 and 5 , which had comparatively low pH values of 11.5 and 11.4 . When S-BA was crushed, the pH was 12.0 , which is comparatively high. Because S-BA had a higher $\mathrm{pH}$ compared with R-BA, hydrogen generation was strongly influenced by factors other than $\mathrm{pH}$.

\subsection{Comparison with theoretical hydrogen gas gen- eration and utility value by engineering}

The S-BA and R-BA contained $3.9 \%$ and $3.8 \%$ of metal aluminum by mass percentage, respectively - if all of the aluminum in the bottom ash reacted then this would correspondingly result in 48.5 and $47.3 \mathrm{~m}^{3} / \mathrm{t}$-ash of hydrogen gas. However, the highest volume of hydrogen gas generated in this study was $12.7 \mathrm{~m}^{3} / \mathrm{t}$-ash (Case 8 ). Comparing the experimental values with theoretical values, hydrogen gas yield of about $26 \%$ was achieved. According to Macanas et al. (2011), an $\mathrm{NaBO}_{2}$ solution is more effective for hydrogen gas generation than other solutions. If a small amount of $0.01 \mathrm{M} \mathrm{NaF}, \mathrm{MgCl}$, or $\mathrm{Fe}_{2}\left(\mathrm{SO}_{4}\right)_{3}$ is added to metal aluminum and water, the amount of hydrogen gas generated increases. Thus, an increase in hydrogen gas generation is expected from those additives.

By crushing S-BA, $6.6 \mathrm{~m}^{3} / \mathrm{t}$-ash of hydrogen gas was generated from S-BA and water within 1 day. Approximately 15,600 tons of bottom and fly ash is generated annually from the $S$ Incineration plant of F city, i.e., we could obtain about $25 \mathrm{~kg}\left(282 \mathrm{~m}^{3}\right)$ of hydrogen gas in a day. Assuming the mileage of a fuel-cell car is $83 \mathrm{~km} / \mathrm{kg}-\mathrm{H}_{2}$, a fuel-cell car could travel for over $2000 \mathrm{~km}$ using the recovered hydrogen gas. This distance is sufficient for fueling a garbage truck, for example. Owing to these reasons, a hydrogen gas recovery system using crushed bottom ash and water is valuable from an engineering standpoint.

\section{CONCLUSIONS}

1) In these experiments, the highest volume of hydrogen generated was $12.7 \mathrm{~m}^{3} / \mathrm{t}$-ash at case 8 (a reaction temperature of $50^{\circ} \mathrm{C}$, liquid-solid ratio of 5 , stirring rate of $600 \mathrm{rpm}$, and with non-crushed R-BA).

2) The optimum temperature for hydrogen generation from MSWIBA exists. In this study, the highest volume

TABLE 2: Amount of hydrogen gas generated and pH after the experiment completed. Cases1-7 represent S-BA and 8-9 represent R-BA.

\begin{tabular}{|c|c|c|c|}
\hline Case & $\begin{array}{c}\text { Hydrogen gas } \\
\text { generation time (days) }\end{array}$ & $\begin{array}{c}\text { Hydrogen gas } \\
\text { generation amount }\left(\mathrm{m}^{3} / \mathrm{t}\right)\end{array}$ & pH after experiment \\
\hline 1 & 21.0 & 10.4 & 11.4 \\
\hline 2 & 13.0 & 11.4 & 11.8 \\
\hline 3 & 20.5 & 10.2 & 11.7 \\
\hline 4 & 13.1 & 7.9 & 11.5 \\
\hline 5 & 15.0 & 6.8 & 11.4 \\
\hline 6 & 15.1 & 11.0 & 11.4 \\
\hline 7 & 1.1 & 6.6 & 12.0 \\
\hline 8 & 4.1 & 12.7 & 11.0 \\
\hline 9 & 1.8 & 5.1 & 10.9 \\
\hline
\end{tabular}


of hydrogen gas was generated at $50^{\circ} \mathrm{C}$.

3) When $\mathrm{l} / \mathrm{s}=5$ more hydrogen gas was generated than when $\mathrm{l} / \mathrm{s}=3$ scenario. The reason for the lower amount of hydrogen gas generated could have been that mixing between bottom ash and water was insufficient due to a water shortage at $\mathrm{l} / \mathrm{s}=3$.

4) At stirring rates of 600 and $800 \mathrm{rpm}$ more hydrogen gas was generated than at a stirring rate of $400 \mathrm{rpm}$. This could be because bottom ash and water were not well mixed at $400 \mathrm{rpm}$.

5) By crushing bottom ash, the initial gradient of hydrogen gas generation dramatically increased, but the cumulative volume produced did not increase. In this study, the initial gradient of hydrogen gas generation increased from 3.8 to $274.5 \mathrm{~m}^{3} / \mathrm{t}$-ash/day in the case of S-BA, and from 8.2 to $135.1 \mathrm{~m}^{3} / \mathrm{t}$-ash/day in the case of R-BA.

6 ) In this study, the maximum amount of hydrogen gas yield was about $26 \%$ of the theoretical hydrogen gas generation amount.

From the above, to generate a large volume of hydrogen gas within a short period of time by mixing and stirring bottom ash with water, it is desirable to set the reaction temperature to at least $50^{\circ} \mathrm{C}$, and the minimum stirring rate of $600 \mathrm{rpm}$. If the shape of the stirring blade and the reactor are optimized, however, even if the liquid-solid ratio is reduced to less than 5 , or the stirring rate is reduced to less than $600 \mathrm{rpm}$, the amount of hydrogen gas generation would not decrease as it did in this study.

\section{ACKNOWLEDGEMENTS}

This study was supported by JSPS KAKENHI Grant Number JP16H04438. The authors wish to acknowledge TAKUMA Co. Ltd. for technical advice concerning practical use.

\section{REFERENCES}

Armstrong, R.D., \& Braham, V.J. (1996). The mechanism of aluminum corrosion in alkaline solutions. Corros Sci, 38, 1463-1471.

Arumugam, N. (2016). Hydrogen gas evolution in Municipal Solid Waste Incineration (MSWI) bottom ash residues. Kyushu university doctoral dissertation.

DeLuchi, M.A. (1989). Hydrogen vehicles: an evaluation of fuel storage, performance, safety, environmental impacts, and cost. International Journal of Hydrogen Energy, 14(2), 81-130.

Granovskii, M., Dincer, I., \& Rosen, M.A. (2006). Economic and environmental comparison of conventional, hybrid, electric and hydrogen fuel cell vehicles. Journal of Power Sources, 159(2), 1186-1193.

Macanas, J., Soler, L., Candele, A.M., Muñoz, M., \& Casado, J. (2011) Hydrogen generation by aluminum corrosion in aqueous alkaline solutions of inorganic promoters: The AlHidrox process. Energy, 36(5), 2493-2501.

Marbán, G., \& Valdés-Solís, T. (2007). Towards the hydrogen economy?. International Journal of Hydrogen Energy, 32(12), 1625-1637.

Mierlo, J.V., Maggetto, G., \& Lataire, Ph. (2006). Which energy source for road transport in the future? A comparison of battery, hybrid and fuel cell vehicles. Energy Conversion and Management, 47(17), 2748-2760.

Ministry of the Environment of Japan. (2017). Results of actual survey on municipal solid waste: results of fiscal year 2015. Retrieved from http://www.env.go.jp/recycle/waste_tech/ippan/h27/index. html.

Momirlan, M., \& Veziroglu, T. (2002). Current status of hydrogen energy. Renewable and Sustainable Energy Reviews, 6(1-2), 141-179.

Momirlan, M., \& Veziroglu, T.N. (2005). The properties of hydrogen as fuel tomorrow in sustainable energy system for a cleaner planet. International Journal of Hydrogen Energy, 30(7), 795-802.

Saffarzadeh, A., Mrumugam, N., \& Shimaoka, T. (2016). Aluminum and aluminum alloys in municipal solid waste incineration (MSWI) bottom ash: A potential source for the production of hydrogen gas. INTERNATIONAL JOURNAL OF HYDROGEN ENERGY, 41, 820-831.

Shinnar, R. (2003). The hydrogen economy, fuel cells, and electric cars. Technology in Society, 25(4), 455-476.

Takatsuki, H. (1994). Conclusions Drawn from an Accidental Explosion at a Dust Bunker. Haikibutsu Gakkaishi, 5(5), 441-448.

Toyofuku, H. (1989). Relationship between municipal solid waste incineration ash and hydrogen gas at a municipal solid waste incinerator. Nihonkankyoeiseisentah Shohou, 16, 51-59.

Zhao, Z., Chen, X., \& Hao, M., (2011). Hydrogen generation by splitting water with Al-Ca alloy. Energy, 36(5), 2782-2787. 